\title{
If the Bible is Literally True, Adam and Eve were Most Likely Platinum Blonde Caucasians
}

\author{
Mister Seun Ayoade* \\ Physiology, University of Ibadan, Nigeria
}

Submission: February 18, 2018; Published: February 26, 2018

*Corresponding author: MISTER SEUN AYOADE, BSc (Hons) Physiology, University of Ibadan, oyo State, Nigeria, Email: seunoodua@yahoo.com

\section{Abstract}

For centuries, virtually all depictions: paintings, drawings, carvings, mosaics, tapestries and movies etc. of Adam and Eve have shown the duo as being Caucasians- often having blonde hair. In today's ultra-politically correct world, believers in Intelligent design and creationism are trying to sidestep this hot potato issue about what Adam and Eve looked like. They often say Adam and Eve had to have been "medium brown" or "golden brown" in colour, as they had within them the genes/genetic information to produce all the divergent races of man [1-2] This is a politically correct, condescending and 'inclusive' argument that makes people (especially non Caucasians) happy, but it is not scientific. Adam and Eve did not have to be "middle brown" to produce blacks, Orientals, 'Asiatic' etc. If Adam and Eve did indeed really exist and are the parents of all people, Adam and Eve most likely were platinum blonde Caucasians.

According to the literalist interpretation of the Bible, there were only two original human beings from which every other human being that has ever existed descended. In fact there was first only one human being who married what can be described as his bone transplant (Eve).

If this is true, it would imply inbreeding [3-4] had to have taken place among the children and other descendants of these two pristine human beings at least for a few generations. Inbreeding initially highlights and increases some traits but eventually reduces phenotypic variation. To put this simply: in the short term inbreeding maximizes some characteristics but in the long term limits characteristics (unless foreign blood is injected again i.e. out breeding). Inbreeding is the Biblical explanation (according to some creationists) for the different races of man today. However the most phenol typically varied race today is Caucasian. Thus it logically follows that the closest thing to what Adam and Eve looked like would be an extreme Caucasian- a platinum blonde. A platinum blonde is an extreme blonde with silvery white hair. As an African, this realization is slightly disturbing. However it is the most reasonable and scientific conclusion. Here's why

\section{Introduction}

A lot of physical features are used to describe the "races" of humanity today and there's no need to go into all of them here-I will only deal with the major feature that causes and has always caused all the hubbub about race and racism i.e. colour. This includes skin colour, hair colour and eye colour. Skin, eye and hair colour are all determined by melanin which is produced by melanocytes. Types of melanin include eumelanin, pheomelanin and neuromelanin.

Today Caucasians show the greatest variety of hair and eye colour. Thus there are Caucasians with blue, brown, green, hazel eyes etc. There are also Caucasians with platinum, brunette, blonde, red, chestnut hair etc. Among all other "races" however the eyes are almost always brown and the hair is almost always black.

If Adam and Eve were Caucasian, it means they had little melanin in them [hence their white skin complexion], but had the genetic potential to produce offspring with more melanin, if their children were inbred. Assuming Cane and Abel married their sisters and produced children, there would be a higher probability of their children (Adam's grandchildren) having more melanin in their skin, hair and eyes than their parents juxtaposed to having less melanin than their parents. After the tower of Babel collapsed and new communities inbred even further, melanin content would have increased and increased to the limit it could (Africans), although once in a while you would still have black parents giving birth to white children. After a certain number of generations however melanin levels would have reached the level of reduced phenotypic variation; and all children born thereafter would be black.

Thesame reasoning appliesto other phenotypiccharacteristics. Adam could not have been black or medium brown with brown eyes, with his ancestors becoming successively lighter with blue eyes. The concept of dominant and recessive genes completely destroys that theory. If there really was an Adam, it is so much more likely, probable and logically and scientifically feasible that he was a platinum blonde Caucasian with light eyes, and that over time his descendants became darker due to inbreeding and probably some nutritional and environmental factors. 


\section{Summary}

If the Bible is literally true and all 8 billion of us on earth today are descended from only two individuals called Adam and Eve, it would mean the children and grandchildren of Adam and Eve initially had to marry their siblings and mate within the same family. This is called inbreeding and causes certain characteristics to be amplified e.g. melanin levels. This would account for the skin, eye and hair colour differences of the various people on earth. If Adam and Eve were black or medium brown, inbreeding would have resulted in darker descendants and very rarely lighter ones. In short, if Adam and Eve were black/brown everybody on earth today would be black skinned and black haired and the only whites would be albinos. In the long term, inbreeding causes limits in physical characteristics. Inbreeding results in homozygosis.

Caucasians today show greater variations than any other people in melanin related physical characteristics. Logically, therefore if Adam and Eve existed they had to have been extreme Caucasians (platinum blondes). The reverse (a black or medium brown Adam) is scientifically/genetically impossible, because of the long term effects of inbreeding and the nature of dominant and recessive genes. People of faith should find the above speculations intriguing. Personally, I like to joke that the reason all shades and colours of human hair turn grey as we age is to pay homage to our greatest grandfather and ancestor-platinum blonde haired Adam.

\section{References}

1. (2016) Adam + Eve= All Skin Tones? Answers in Genesis

2. What Colour Was Adam?

3. Inbreeding At Encyclopaedia Britannica

4. R Soper (1997) Biological Science ( $3^{\text {rd }}$ edn), Cambridge University Press Edited, India, pp. 917.

\section{Your next submission with Juniper Publishers} will reach you the below assets

- Quality Editorial service

- Swift Peer Review

- Reprints availability

- E-prints Service

- Manuscript Podcast for convenient understanding

- Global attainment for your research

- Manuscript accessibility in different formats ( Pdf, E-pub, Full Text, Audio)

- Unceasing customer service

Track the below URL for one-step submission https://juniperpublishers.com/online-submission.php 